\title{
International Law and Dual Nationality of Hungarians Living Outside the Borders
}

\begin{abstract}
According to the recent amendment of the Hungarian Citizenship Act, Hungarians living outside the borders can acquire an additional nationality, and become dual or multiple nationals. The study analyses the prohibition or recognition of dual nationality and the relevant practice of neighbouring states as the main purpose of the amendment was to enable Hungarians living in territories detached owing to historical events to acquire nationality. By assuming international obligations states may limit their discretion in matters of nationality, which otherwise fall within the domestic jurisdiction of states. Human rights drive the regulation of nationality in certain cases all the more towards the realm of international law. For that reason, human rights limiting the regulation of nationality, such as the right to a nationality, the prohibition of (arbitrary) deprivation of nationality and the prohibition of discrimination, also need to be examined. The analysis also extends to the lack of effectiveness of nationality of Hungarians concerned as well as the binding nature of the principle of effectiveness. The study concludes that the principle of effectiveness may not serve as a basis for other states to declare non-recognition of nationality of these individuals. Finally, obligations under bilateral treaties on good neighbourliness, confidence and friendly co-operation concluded by Hungary and several neighbouring states between 1992 and 1996 are taken into consideration, as well.
\end{abstract}

Keywords: dual nationality, statelessness, right to a nationality, prohibition of (arbitrary) deprivation of nationality, prohibition of discrimination, domaine réservé, principle of effectiveness

\section{Introduction}

The recently amended Hungarian Citizenship Act ${ }^{1}$ provides for a preferential naturalisation of Hungarians living outside the borders. According to the amendment, a non-Hungarian citizen, ${ }^{2}$ whose ascendant was a Hungarian citizen, or who demonstrates the plausibility of

* Young researcher, junior research fellow, Institute for Legal Studies, Centre for Social Sciences, Hungarian Academy of Sciences, H-1014 Budapest, Országház u. 30; Assistant lecturer, Széchenyi István University, Deák Ferenc Faculty of Law and Political Sciences, Department of Private and Public International Law, H-9026 Györ, Áldozat u. 12.

E-mail: ganczermonika@yahoo.com

1 Act No. LV of 1993 on Hungarian Citizenship, Art. 4(3).

2 The notions of "citizenship" and "nationality" need to be distinguished on the basis of their nature in domestic law and international law. "Citizenship" includes the rights and obligations of a person originating from his citizenship. See Moore, J. B.: A Digest of International Law as Embodied in Diplomatic Discussions, Treaties and Other International Agreements, International Awards, the Decisions of Municipal Courts, and the Writings of Jurists, and Especially in Documents, Published and Unpublished, Issued by Presidents and Secretaries of State of the United States, the Opinions of the Attorneys-General, and the Decisions of Courts, Federal and State. Vol. III. Washington, 1906. 273. § 372; Hyde, Ch. Ch.: International Law Chiefly as Interpreted and Applied by the United States. Vol. II. Boston, 1945. 1066-1067; Garay, J. C.: La théorie de la citoyenneté automatique des étrangérs. Revue de Droit International, 4 (1926) 1, 135; Isay, E.: De la nationalité. Recueil des Cours, 5 (1924) 4, 432; Cogordan, G.: Droit des gens. La nationalité au point de vue des rapports internationaux. Paris, 1879. 6. Since the existence of citizenship rights and obligations are relevant from the point of 
his or her descent from Hungary and provides proof of his or her knowledge of the Hungarian language may-on his or her request-be naturalized on preferential terms since 1 January 2011. The changes compared to the previous version of the Act are that the criteria of assured livelihood and permanent residence in Hungary as well as the requirement of an exam in basic constitutional studies have been waived.

The main purpose of the broad wording of the phrase "whose ascendant was a Hungarian citizen, or who demonstrates the plausibility of his or her descent from Hungary" is to enable Hungarians and their descendants living in territories detached during the 20th century to acquire Hungarian citizenship. In addition, that wording also embraces those, who emigrated in the meantime and lost their citizenship.

The first significant group of Hungarians living outside the borders emerged in the wake of the Peace Treaty of Trianon of $1920 .{ }^{3}$ In the course of territorial revisions between 1938 and 1941, a number of Hungarians received back their Hungarian citizenship. ${ }^{4}$ However, at the end of the Second World War, Para. 2 of the Armistice Agreement of $1945^{5}$ stipulated that the borders of Hungary must be re-established in line with their status as of 31 December 1937, and any acts and administrative decisions relating to the territorial revisions must be terminated. ${ }^{6}$ Hence, from among the persons, who acquired Hungarian

view of domestic law, the term "citizenship" is mainly used as a notion of domestic law. See Koessler, M.: "Subject," "Citizen," "National," and "Permanent Allegiance". The Yale Law Journal, 56 (19461947), 62-63. "Nationality" primarily means the belonging of an individual to a state irrespective of citizenship rights and obligations. See Minor v. Happersett, 88 U.S. 162 (1874); Romano v. Comma, (Egyptian Mixed Court of Appeal), 12 May, 1925. Annual Digest of Public International Law Cases, 1925-1926. Case No. 195., 265. For analyses focusing on nationality in international law, it is the bond between the individual and the state that has significance; the existence of rights and obligations is irrelevant. Consequently, the term "nationality" has to be used in international law.

3 Treaty of Peace between the Allied and Associated Powers and Hungary. Trianon, 4 June 1920. Entry into force: 31 July 1921. Arts 61-66.

${ }^{4}$ Arbitral award establishing the Czechoslovak-Hungarian boundary, Vienna, 2 November 1938. Annex, Para. 4. Reports of International Arbitral Awards, Vol. XXVIII. 405. Agreement between the Kingdom of Hungary and the Republic of Czechoslovakia on regulation on citizenship according to arbitral award in Vienna on 2 November 1938, Budapest, 18 February, 1939. For more details concerning the arbitral award see Kovács, P.: A propos du chemin vers l'arbitrage de Vienne de 1938. In: Kovács, P. (ed.): International Law-A Quiet Strength. Le droit international, une force tranquille (Miscellanea in memoriam Géza Herczegh). Budapest, 2011. 31-70. Between 15 and 18 March 1939, the Hungarian army invaded the territory of Sub-Carpathia. The ensuing questions of nationality were regulated in Hungarian domestic law by Section 5 of Act No. VI of 1939. Award relating to the Territory ceded by Romania to Hungary, 30 August 1940. Paras 3-4. Reports of International Arbitral Awards, Vol. XXVIII. 410. Certain elements of the Second Vienna Arbitral Award became part of Hungarian domestic law by way of Section 4 of Act No. XXV of 1940. Territories of the South were re-annexed after the invasion of the Hungarian army on 11 April 1941. The ensuing questions of nationality were regulated in Hungarian domestic law by Section 4 of Act No. XX of 1941.

5 Agreement concerning an armistice between the Union of Soviet Socialist Republics, the United Kingdom of Great Britain and Northern Ireland, and the United States of America on one hand and Hungary on the other. Moscow, 20 January 1945. Entry into force: 20 January 1945.

6 Decree No. 526/1945. M. E. executed the Para. 2 of the Armistice Agreement by stating the repealing Acts relating to territorial changes after 1937. 
nationality in the course of territorial revisions, only those could retain it, who had transferred their permanent residence into the territory of the state as of 31 December $1937 .^{7}$

Even though the amendment had a primarily symbolic purpose by granting citizenship to Hungarians, who or whose ascendants lost their Hungarian citizenship in consequence of historic events and hitherto could not retrieve it for lack of residency in Hungary, this measure and the reactions of neighbouring states have raised several questions of international law.

\section{Prohibition or Recognition of Dual Nationality}

In accordance with the amendment Hungarians living outside the borders can acquire a second nationality in addition to their existing one, and as such become dual nationals provided that the state of their former nationality recognises dual or multiple nationality (hereinafter: dual nationality). The international community is divided on this matter: a number of the states recognise dual nationality, while others refuse it.

\section{Prohibition or Recognition of Dual Nationality in International Law}

It is generally accepted that matters on nationality-as derived from the sovereignty of states-fall within the domestic jurisdiction of states, and form part of domaine réservé. ${ }^{8}$ Domaine réservé includes matters in which states enjoy absolute and unrestricted discretion. The determination of conditions of the granting and loss of nationality as well as the prohibition or recognition of dual nationality also count among these matters. However, the discretion of states likewise includes the undertaking of international obligations concerning these matters, whereby states may establish limits on their own. ${ }^{9}$ The undertaking of an international obligation "places a restriction upon the exercise of the sovereign rights of the [s]tate", ${ }^{10}$ but limits cannot be presumed in the lack of will of the state. ${ }^{11}$ Therefore, the sovereignty of states and the limits of international law on matters of nationality "are well

7 According to Section 1 of the Decree No. 5.070/1945. M. E., individuals, who acquired Hungarian citizenship on the basis of the repealed Acts, but their permanent residency was in the territory of Hungary as of 31 December 1937 at the time of entry into force of the Decree, that is on 21 July 1945, could remain Hungarian citizens.

8 See the opposite opinion of Hans Kelsen: "[T]here are no matters which [...] are 'solely' [...] [or] 'essentially' within the domestic jurisdiction of a state" as long as any matter "acquisition or loss of citizenship [...] may [also] be the object of an international agreement. The fact that these matters are, normally, not regulated by a rule of international law is no reason to assume that they are 'essentially' within the domestic jurisdiction of the states." Kelsen, H.: The Law of the United Nations. A Critical Analysis of Its Fundamental Problems. London, 1951. 776.

9 See the opposite opinion of Hans Kelsen: "Although the individual states remain competent, in principle (even under international law) to regulate everything, they retain their competence only so far as international law does not regulate a subject matter and thereby withdraws it from free regulation by national law. Under the assumption of international law as a supranational legal order, the national legal order, then, has no longer an illimitable competence (Kompetenzhoheit)." Kelsen, H.: Pure Theory of Law. Clark, 2005. 338.

10 The S.S. Wimbledon (Great Britain, France, Italy, Japan, and Poland v. Germany), Permanent Court of International Justice, Judgment of 17 August 1923. P.C.I.J. Series A, No. 1, 25.

11 The S.S. Lotus (France v. Turkey), Permanent Court of International Justice, Judgment of 7 September 1927. P.C.I.J. Series A, No. 10, 18. 
compatible". ${ }^{12}$ The prohibition or recognition of dual nationality is governed by international law to such extent only as the state concerned undertakes international obligations pertaining to that matter.

The practice of states concerning dual nationality can be easily ascertained from their domestic legal regulations and international obligations. Since Hungarians living outside the borders are nationals of neighbouring states, their dual nationality depends on the attitude of neighbouring states.

Notwithstanding that the idea of elimination of dual nationality appeared in the socalled "Bancroft Treaties"13 and in the Convention on certain questions relating to the conflict of nationality laws of $1930,{ }^{14}$ the comprehensive regulation of dual nationality emerged at the beginning of the 1960s, when the main purpose of the international community was to unambiguously prohibit and abolish this phenomenon. The Convention on reduction of cases of multiple nationality and military obligations in cases of multiple nationality under the aegis of the Council of Europe was concluded in such an environment. ${ }^{15}$ According to Art. 1 of that Convention, persons who acquire of their own free will the nationality of another state shall lose their former nationality, if both states are parties to the Convention. Since neither Hungary nor the neighbouring states-with the exception of Austria-are parties to that Convention, the above-mentioned provision is irrelevant.

Concerning another problem arising from dual nationality, that is, the conflict of citizenship rights and obligations of different states, several bilateral agreements have been concluded, which adequately ensure the elimination of its negative consequences and guarantee the enjoyment of its positive features. Suffice it to mention the European Convention on Nationality of $1997^{16}$-to which Hungary and the majority of neighbouring states (Austria, Romania, Slovakia and Ukraine) are also parties. Given that Art. 17 of the Convention deals with the rights and duties related to multiple nationality, and it contains a separate chapter on military obligations in cases of multiple nationality, ${ }^{17}$ the rights and obligations of persons towards the states concerned can be easily distinguished. ${ }^{18}$

12 Triepel, H.: Internationale Regelung der Staatsangehörigkeit. Zeitschrift für ausländisches öffentliches Recht und Völkerrecht, 1 (1929), 197.

13 The "Bancroft Treaties" were concluded by the United States and other states on naturalisation of each other's citizens in the late 19th and early 20th centuries.

${ }^{14}$ Convention on Certain Questions Relating to the Conflict of Nationality Laws. The Hague, 12 April 1930. Entry into force: 1 July 1937. Preamble, Art. 12.

15 Convention on the Reduction of Cases of Multiple Nationality and on Military Obligations in Cases of Multiple Nationality. Strasbourg, 6 May 1963. Entry into force: 28 March 1968.

16 European Convention on Nationality. Strasbourg, 6 November 1997. Entry into force: 1 March 2000.

17 Ibid. Chapter VII.

18 It should be emphasised that Slovakia made the following reservation to Art. 22 on exemption from military obligations or alternative civil service: "According to Art. 22, paragraph b, the Slovak Republic declares that persons who are nationals of a State Party which does not require obligatory military service and who are equally nationals of the Slovak Republic shall be considered as having satisfied their military obligations when they have their habitual residence in the territory of the Slovak Republic." According to this reservation, Slovakia recognises military service in other states depending on the habitual residence in Slovakia-and not depending on the habitual residence in the territory of the state concerned as stated in Art. 22(b)-even if the military service is not obligatory. 


\section{The Practice of Neighbouring States Concerning Dual Nationality}

Romania and Hungary concluded an agreement on the elimination of dual nationality in $1979,{ }^{19}$ in line with the contemporaneous practice of socialist states,${ }^{20}$ but it was terminated in 1990. Currently Romania can be ranked among those states, which recognise dual nationality principally on the basis of the Citizenship Act of $1991 .^{21}$ Romanians, who keep their residency abroad, may acquire citizenship similarly to the Hungarian regulation. The main purpose of this rule is to promote the gaining of dual citizenship for Romanians living in Moldova. Constitution of Romania refers the regulation of nationality to the Citizenship Act, as an organic law, ${ }^{22}$ which does not consider the acquisition of another nationality as a ground for the loss of Romanian nationality. ${ }^{23}$ Consequently there is no rule in Romania on the prohibition of dual nationality, and Hungarians living in Romania can become dual nationals after requesting Hungarian nationality.

Croatia, Serbia and Slovenia recognise dual nationality and allow the acquisition of another nationality for those living outside the borders similarly to the Hungarian and Romanian regulations. The Serbian Citizenship Act of $2004^{24}$ does not mention the elimination of dual nationality; what is more, it offers the acquisition of nationality for Serbs living abroad. Since the domestic legal regulation of Serbia is similar to rules of the Hungarian Citizenship Act, Serbia obviously does not oppose it. The same holds true for the Croatian Citizenship Act of 1991, which likewise allows the acquisition of citizenship by Croats even without a domicile in Croatia. ${ }^{25}$ The Slovenian Citizenship Act of $1991^{26}$ and the Act concerning the Settlement of the Status of Citizens of Other SFRY Successor States in the Republic of Slovenia of $1999^{27}$ recognise dual nationality, as well.

Contrary to the above-mentioned states, Ukraine unambiguously prohibits dual nationality; consequently Hungarians living in Ukraine lose their Ukrainian nationality upon the acquisition of Hungarian nationality. In addition to the Constitution of Ukraine, ${ }^{28}$ the Citizenship Act of $2001^{29}$ also states that the state recognizes only one citizenship per person; therefore in case someone gains another citizenship he or she will automatically lose his or her Ukrainian citizenship.

19 Agreement between People's Republic of Hungary and Socialist Republic of Romania on Solution and Prevention of Cases of Dual Nationality. Bucharest, 13 July 1979. Entry into force: 10 February 1980. The Law regarding Romanian Citizenship No. 21 of 1 March 1991.

${ }^{20}$ Hungary concluded such agreements with Bulgaria, Czechoslovakia, the German Democratic Republic, Mongolia, Poland and the Soviet Union, between 1958 and 1981. All of them were terminated between 1990 and 1994 for different reasons. See Ugróczky, M.: Az állampolgárság szabályozása Európában (Regulation of Nationality in Europe). Acta Humana, 10 (1999) 37-38, 63.

${ }^{21}$ Law No. 21 of 1991 regarding Romanian Citizenship, Art. 11.

22 Constitution of Romania, Art. 5.

${ }^{23}$ Law No. 21 of 1991 regarding Romanian Citizenship, Chapter 5 on losing Romanian citizenship.

${ }^{24}$ Law on Citizenship of the Republic of Serbia of 2004.

25 Act on Croatian Citizenship of 1991, Arts 11 and 16.

${ }^{26}$ Citizenship Act of the Republic of Slovenia of 1991.

27 The settling of the status of citizens of other SFRY Successor States in The Republic of Slovenia Act No. 61/99 of 1999.

28 Constitution of Ukraine, Art. 4.

${ }^{29}$ Law on Citizenship of Ukraine of 2001, Art. 2. 
Austria also belongs to the group of states, which refuses dual nationality. ${ }^{30}$ This statement is well illustrated by the fact that from among the neighbouring states Austria is the sole party to the Convention on reduction of cases of multiple nationality and military obligations in cases of multiple nationality of 1963. According to the Federal Law concerning Austrian Nationality of $1985,{ }^{31}$ a person, who acquires a foreign nationality upon his application, his or her declaration or express consent brings about the loss of Austrian nationality, unless he or she was not previously granted the right to retain that nationality. Therefore, a person will lose his or her Austrian nationality in consequence of acquiring Hungarian nationality, unless he or she was not permitted to retain it.

Slovakia is the only country that responded to the Hungarian amendment by legal means. According to the rapidly passed amendment to the Slovak Citizenship Act, ${ }^{32}$ which entered into force on 17 July 2010, persons automatically lose their Slovak citizenship, who voluntarily acquire another nationality, with the exception of those, who gain it through birth or marriage. In this manner, with a view to avoid the dual nationality of persons belonging to the Hungarian minority, Slovakia abandoned her former practice, according to which dual nationality was recognised and accepted.

Until 2010, pursuant to the Slovak Citizenship Act, ${ }^{33}$ Slovak citizenship could only be lost upon an explicit personal request for release from the state bond. There existed no regulation concerning the loss of citizenship of dual citizens; moreover several conditions were required for the elimination of the bond of citizenship. Besides, Slovakia, a member state of the Council of Europe, is not a party to the above-mentioned Convention of 1963.

It is worth noting that a bilateral agreement was concluded by Czechoslovakia and Hungary in 1960, according to which persons possessing the nationality of both states had to make a choice and decide which nationality they wish to retain. Following the dissolution of Czechoslovakia in 1992, the two states should have had to demonstrate that they regarded the treaty as effective in order to keep it in force. Hungary did not make a statement on this matter; what is more, the act that promulgated the treaty was revoked. Slovakia also should have made a notification of succession regarding the agreement, but it did not come to pass according to the available and conflicting pieces of information. It appears, therefore, that Slovakia has changed her former practice and joined the group of states, which refuse dual nationality.

The overview of domestic regulations and international obligations of neighbouring states reveals that Croatia, Romania, Serbia and Slovenia recognise dual nationality, whereas Austria, Slovakia and Ukraine prohibit it. Hungarians living in the latter three states will lose their nationality, if they voluntarily acquire Hungarian nationality on the basis of the amendment of the Hungarian Citizenship Act.

30 It is worth mentioning Decision No. 1217/B/1991. of the Constitutional Court at this point. In that case, the applicant presented that the precondition of acquisition of Austrian nationality by way of naturalisation was the loss of his former Hungarian nationality.

${ }^{31}$ Federal Law concerning Austrian Nationality of 1985, Art. 27(1).

32 Law of Slovak National Council of 19th January 1993 regarding Citizenship of Slovak Nationality.

33 Ibid. Art. 9. 


\section{Human Rights Obligations of States Concerning Nationality}

Human rights obligations of states limiting the regulation of acquisition and loss of nationality in domestic law, such as the respect for the right to a nationality, the prohibition of (arbitrary) deprivation of nationality and the prohibition of discrimination, need to be examined, as well. The relationship of human rights and the domaine réservé of states can be illustrated, inter alia, by General Assembly Resolution 36/103 of 9 September 1981, ${ }^{34}$ which-unlike the previous resolutions concerning the inadmissibility of intervention ${ }^{35}$ referred to the respect for human rights in the following manner:

"The duty of a State to refrain from the exploitation and the distortion of human rights issues as a means of interference in the internal affairs of States [...]." 36

Five years later, the International Court of Justice also made a remarkable pronouncement in the Nicaragua Case, stressing that "the use of force could not be the appropriate method to monitor or ensure [the] respect [for human rights] [...]." ${ }^{37}$ It may readily be inferred from these statements that human rights issues have already left the realm of domaine reservé by the 1980s. This conclusion can also be substantiated by an important resolution adopted by the Institute of International Law during its session in Santiago de Compostela in 1989, which holds that in case of a breach of human rights obligations, states cannot evade responsibility by claiming that the matter pertains essentially to the reserved domain. ${ }^{38}$ In other words, states "may no longer invoke the inviolability of sovereignty and the principle of non-intervention in case they are being

${ }^{34}$ Declaration on the Inadmissibility of Intervention and Interference in the Internal Affairs of States. G.A. Res. 36/103, 91st plen. mtg., 9 December 1981, U.N. Doc. A/RES/36/103.

35 Declaration on the Inadmissibility of Intervention in the Domestic Affairs of States and the Protection of Their Independence and Sovereignty. G.A. Res. 2131, 1408th plen. mtg., 21 December 1965, U.N. Doc. A/RES/2141; Declaration on Principles of International Law concerning Friendly Relations and Co-operation among States in accordance with the Charter of the United Nations. G.A. Res. 2625, 1883rd plen. mtg., 24 October 1970, U.N. Doc. A/RES/2625, Annex; Declaration on the Strengthening of International Security. G.A. Res. 2734, 1932nd plen. mtg., 16 December 1970, U.N. Doc. A/RES/2734; Non-interference in the international affairs of States. G.A. Res. 31/91, 98th plen. mtg., 14 December 1976, U.N. Doc. A/RES/31/91; Non-interference in the international affairs of States. G.A. Res. 32/153, 106th plen. mtg., 19 December 1977, U.N. Doc. A/RES/32/153; Noninterference in the international affairs of States. G.A. Res. 33/74, 85th plen. mtg., 15 December 1978, U.N. Doc. A/RES/33/74; Non-interference in the international affairs of States. G.A. Res. 34/101, 103rd plen. mtg., 14 December 1979, U.N. Doc. A/RES/34/101; Non-interference in the international affairs of States. G.A. Res. 35/159, 94th plen. mtg., 12 December 1980, U.N. Doc. A/RES/35/159.

36 Declaration on the Inadmissibility of Intervention and Interference in the Internal Affairs of States. G.A. Res. 36/103, 91st plen. mtg., 9 December 1981, U.N. Doc. A/RES/36/103, Annex, para 2.(II)(1).

37 Case concerning Military and Paramilitary Activities in and against Nicaragua (Nicaragua v. United States of America), International Court of Justice, Merits, Judgment of 27 June 1986. I.C.J. Reports 1986. (para 268.) 134.

38 Institut de Droit International, La protection des droits de l'homme et le principe de nonintervention dans les affaires intérieures des Etats. Session de Saint-Jacques-de-Compostelle, 1989. Article premier, Art. 2. 
criticized for serious breaches of human rights." ${ }^{39}$ For these reasons, the removal of human rights issues from the domaine réservé of states thrusts the regulation of nationality in certain cases all the more into the realm of international law.

\section{Right to a Nationality and Prohibition of Deprivation of Nationality}

In recent times, states that refuse dual nationality are occasionally criticised on the basis of the prohibition of deprivation of nationality. The case of losing nationality as a consequence of the acquisition of Hungarian nationality needs to be analysed from the point of view of its conformity with international law.

Austria, Slovakia and Ukraine are equally obliged by international instruments, which contain the prohibition of deprivation of nationality. Such instruments include the Universal Declaration of Human Rights of $1948,{ }^{40}$ and the European Convention on Nationality of 1997.

The provision of the Universal Declaration of Human Rights, which states that "[e] veryone has a right to a nationality", ${ }^{41}$ was subsequently taken over by the European Convention of Nationality. ${ }^{42}$ The records of debates that took place during the drafting of the Universal Declaration of Human Rights suggest that the purpose of this provision was to ensure protection against statelessness, ${ }^{43}$ but the obscure phrasing leaves room for divergent interpretations. The indefinite article "a" before the expression "nationality" is similar to the numeral "one" in certain languages-for example, "une" in French stands for either an indefinite article or a numeral. ${ }^{44}$ Consequently, an absurd theory emerged, according to which the right to a nationality actually means the right to one nationality, ${ }^{45}$ and serves as a means to eliminate dual nationality. Due to the fact that the purpose of regulation was undoubtedly to eliminate statelessness, neither a human right of dual nationality, ${ }^{46}$ nor a prohibition of dual nationality can be deduced from the provision under consideration.

According to the generally accepted view, the right to a nationality includes the right to acquisition and retention of nationality. ${ }^{47}$ Notwithstanding that scholarly opinions

39 Sulyok, G.: 2. § [Függetlenség] (2. § [Independence]). In: Jakab, A. (ed.): Az Alkotmány kommentárja I. (Commentary of the Constitution I.). Budapest, 2009. 141.

40 Universal Declaration of Human Rights. G.A. Res. 217A, 183rd plen. mtg., 10 December 1948. U.N. Doc. A/RES/217A (III). As generally known, the Declaration is a resolution adopted by the United Nations General Assembly. Even though the resolutions of that organ are not legally binding, the Declaration have become binding as customary international law.

41 Universal Declaration of Human Rights, Art. 15(1).

42 European Convention on Nationality, Art. 4(a).

43 Verdoodt, A.: Naissance et signification de la Déclaration universelle des droits de l'homme. Louvain, 1964. 156-161.

${ }^{44}$ Real content of the paragraph is expressed exactly by the expression "valamely" in Hungarian translation.

45 Griffin, W. L.: The Right to a Single Nationality. Temple Law Quarterly, 40 (1966-1967), 57-64.

46 Spiro, P. J.: Dual citizenship as human right. International Journal of Constitutional Law, 8 (2010) 1, 111-130.

47 Chan, J. M. M.: The Right to a Nationality as a Human Right. The Current Trend Towards Recognition. Human Rights Law Journal, 12 (1991) 1-2, 3. 
significantly differ concerning the right to change nationality as that particular right is related to the disposition of nationality rather than to the elimination of statelessness.

The prohibition of deprivation of nationality cannot be directly deduced from the right to a nationality, albeit it is closely linked thereto, and as such, it generally follows the right to a nationality in international instruments. The epithets "arbitrary" and "unlawfully" are frequently attached as attributes to the prohibition of deprivation, but their interpretation gives rise to heated debates. "Arbitrary" as an attribute is used by the Universal Declaration of Human Rights and the European Convention on Nationality, while "unlawful" appears alongside "arbitrary" in the Convention on the Rights of Child of 1989.

The Universal Declaration of Human Rights includes the prohibition of arbitrary deprivation of nationality without offering a definition of arbitrariness. If the right to a nationality is considered as a fundamental human right, any deprivation of nationality that results in statelessness can be labelled as "arbitrary" as it would be blatantly incompatible with the purposes of the Declaration. It should be added that the Convention on the Reduction of Statelessness of 1961 stipulates that states shall not deprive a person of his or her nationality, if such deprivation would render him or her stateless. The text of the prohibition, however, does not contain any epithets.

Consequently, the prohibition of arbitrary deprivation of nationality does not cover dual or multiple nationals, who will possess at least one nationality after losing a nationality through deprivation. This can be illustrated by Art. 7 the European Convention of Nationality that, in addition to the prohibition of arbitrary deprivation of nationality in Art. 4(c), permits states to provide for the loss of nationality in their domestic enactments either ex lege, or at the initiative of the state, in case a person voluntarily acquires another nationality. ${ }^{48}$ In addition, the Explanatory Report to the European Convention on Nationality ${ }^{49}$ gives indications concerning the prevention of arbitrary deprivation of nationality. As regards the substantive grounds, "the deprivation must in general be foreseeable, proportional and prescribed by law" ${ }^{50}$ A deprivation is also arbitrary, if it is based on any of the grounds contained in Art. 5(1) on the prohibition of discrimination. The Explanatory Report refers to Art. 7 for an exhaustive list of grounds for deprivation, which likewise proves that an ex lege loss of nationality in consequence of a voluntary acquisition of another nationality cannot be deemed arbitrary. ${ }^{51}$

The prohibition of denying the right to change nationality in the Universal Declaration of Human Rights entails the prohibition of deprivation of both the renunciation of nationality and the acquisition of another nationality. It cannot be construed, however, as a prohibition of deprivation of and a right to retain the former nationality, since the expression "change" suggests the loss of that nationality.

In sum, the regulation of certain states, according to which persons lose their nationality in consequence of the acquisition of another nationality, is in conformity with international law. The loss of former nationality in Austria, Slovakia and Ukraine cannot be evaluated as an arbitrary deprivation of nationality.

48 European Convention on Nationality, Art. 7(1)(a).

49 Explanatory Report to the European Convention on Nationality. Available at $<\mathrm{http} / /$ conventions.coe.int/Treaty/en/reports/html/166.htm> (26 March 2012).

50 Ibid. para 36.

51 Ibid. 
These regulations should be analysed not only in the context of international law, but also in the context of domestic law. In particular, the harmony of the Constitution of Slovakia and the amendment of the Citizenship Act calls for thorough examination. According to the Constitution "[n]o one shall be deprived of citizenship of the Slovak Republic against his or her will".52 This provision begs the question: Can a request for Hungarian nationality be regarded as an intention of the person to give up his or her Slovak nationality? It can reasonably be argued that a request by a person for another nationality cannot be interpreted as a loss of nationality on his or her own will, even if he or she is aware of the consequences of that action, namely the loss of Slovak nationality. The will of the person concerned only covers the acquisition of Hungarian nationality, from which the intention of losing Slovak nationality cannot be convincingly deduced. According to the Constitution, the Slovak nationality can only be lost by way of renunciation, but this case does not involve such a renunciation. ${ }^{53}$ The authoritative clarification of this issue is solely within the competence of the Constitutional Court of Slovakia.

\section{Prohibition of Discrimination}

A possible violation of the prohibition of discrimination may occur in Slovakia from among the neighbouring states. It is open to debate whether the Citizenship Act is discriminative as it recognises dual nationality in two cases: if the other nationality is acquired by birth or marriage. The European Convention on Nationality expressly mentions the recognition of dual nationality, if another nationality is automatically acquired by birth or marriage, thus the exceptions of the Act seem to be generally accepted at first glance. It is obvious that permitting a child to become a dual national at birth is not discriminative, since he or she acquires the other nationality automatically, rather than on request. However, in a case of marriage the situation is completely different, since the Act only recognises dual citizenship, if the Slovak citizen acquires another nationality in connection with a marriage with a foreign citizen, by the existence of that marriage. The legislator presumably had an automatic acquisition in mind, but the text does not reflect it unambiguously. Hence it seems that in cases of marriage both automatic acquisition and acquisition at request are allowed. If either party gains another nationality at request, discrimination between cases on facts may occur, because in this case the Slovak nationality can be retained, whereas in every other scenario the request of another nationality brings about the loss of Slovak nationality.

The Universal Declaration of Human Rights does not explicitly mention the prohibition of discrimination in the context of nationality, but the rule that "everyone is entitled to all the rights and freedoms set forth in this Declaration, without distinction of any kind, [...]" evidently encompasses the right to a nationality as provided for in Art. 15, as well. ${ }^{54}$ Thus

52 Constitution of the Slovak Republic, Art. 5(2).

53 Article 25 of the Citizenship Act of Germany is similar to the regulation of Slovakia, according to which "[a] German shall lose his citizenship upon the acquisition of a foreign citizenship where such acquisition results from his application [...]". Although this rule is in compliance with Art. 16 of the Constitution of Germany, according to which "[n]o one may be deprived of his German citizenship. Loss of citizenship arises only pursuant to law, and against the will of the person affected only if such person does not thereby become stateless."

${ }^{54}$ Article 2 of the Declaration reads as follows: "Everyone is entitled to all the rights and freedoms set forth in this Declaration, without distinction of any kind, such as race, colour, sex, language, religion, political or other opinion, national or social origin, property, birth or other status." 
the Declaration prohibits every kind of discrimination regarding to the right to a nationality as well as to the arbitrary deprivation of nationality. Furthermore, the International Covenant on Civil and Political Rights of $1966^{55}$-to which Slovakia is also a party-demands equality before the law, the prohibition of discrimination on any grounds, and the granting to all persons equal and effective protection against discrimination by the law.

The European Convention for the Protection of Human Rights and Fundamental Freedoms of $1950^{56}$ does not contain the right to a nationality, and provides for the prohibition of discrimination with regard to rights set forth in the Convention only. Even though the Protocol No. 12 to the Convention has since introduced a general prohibition of discrimination, Slovakia is not a party thereto. ${ }^{57}$ The European Court of Human Rights would have jurisdiction over related cases only, if Slovakia violated a right set forth in the Convention or any of its Protocols to which Slovakia is a party. For that reason, both of the above-mentioned European instruments are irrelevant. It does not change the fact, however, that Slovakia is obliged to eradicate all forms of discrimination under international law.

\section{Elimination of Statelessness}

The notion of statelessness is not defined by any of the relevant international instruments. In theory, statelessness has two forms: de jure and de facto statelessness. Those persons are considered de jure stateless, who do not possess the nationality of any state. De facto stateless persons, on the other hand, do possess a nationality in a legal sense, but it is not real as the rights and obligations, which originate from that nationality, cannot be exercised and fulfilled for some reason.

The international community has primarily focused on de jure statelessness, as states have erroneously believed that all de facto stateless persons were refugees. At the United Nations Conference on the Elimination or Reduction of Future Statelessness, the participating states, in addition to the conclusion of the Convention on the Reduction of Statelessness, ${ }^{58}$ adopted a number of resolutions, as well. One of these resolutions declared that "[t]he Conference recommends that persons who are stateless de facto should as far as possible be treated as stateless de jure to enable them to acquire an effective nationality". 59 Naturally, this pronouncement was merely a recommendation for states and had no binding force whatsoever.

It comes from the general purpose of the elimination of statelessness that states should endeavour to abolish both de jure and de facto statelessness. The purpose of the resolution quoted above is to avoid becoming de facto stateless and to achieve a real nationality, which can only be ensured by the state of nationality-consequently, this requirement should be fulfilled by Hungary.

55 International Covenant on Civil and Political Rights, New York, 16 December 1966. Entry into force: 23 March 1976.

56 European Convention for the Protection of Human Rights and Fundamental Freedoms, Rome, 4 November 1950. Entry into force: 3 September 1953.

57 Slovakia signed Protocol No. 12 on 4 November 2000, but has not ratified it yet.

58 Convention on the Reduction of Statelessness, New York, 30 August 1961.

59 United Nations Conference on the Elimination or Reduction of Future Statelessness, Resolution I. 
Subsequent to the loss of their previous nationality, Hungarians living outside the borders possess a nationality, which is, in principle, identical to that of Hungarians living in the territory of Hungary, but in absence of registered residency, employment and tax-paying, they are neither able to exercise several citizenship rights, nor receive a share from social benefits. Even so, they do not become de facto stateless, especially in the light of the right to vote as provided by the new Act on election of the members of Parliament. ${ }^{60}$

\section{Effectiveness of the New Hungarian Nationality}

The analysis of the lack of effectiveness of the nationality of Hungarians, who live outside the borders need to be distinguished from the analysis of de facto stateless status. De facto statelessness manifests itself as the inability of the individual to exercise rights and fulfil obligations of citizenship. The examination of effectiveness, however, focuses on factors other than citizenship rights and obligations, and concentrates on the genuine link between the person and the state. ${ }^{61}$ According to the judgment passed by the International Court of Justice in the Nottebohm Case in 1955, an effective nationality is "based on stronger factual ties" between the person concerned and the state. As stated by the judgment, a factor of utmost importance is "the habitual residence of the individual", "but there are other factors such as the centre of the [person's] interests, his family ties, his participation in public life, attachment shown by him for a given country and inculcated in his children, etc." $" 62$

In addition to the absence of effectiveness, individuals frequently lack citizenship rights and obligations, although it does not originate from the absence of effectiveness. Such coincidences typically result from the similar features of requirements formulated by states concerning the factors indicating the existence of effectiveness and the exercise and fulfilment of rights and duties of citizenship.

Several individuals currently applying for citizenship have previously had Hungarian citizenship, and as such, some sort of link exists between them and Hungary, even though their permanent residence can be found elsewhere and they habitually live and work in another country, usually along with their families. The bond with Hungary is less genuine in case of those individuals, who were born and live in the territory of another state, barely speak Hungarian ${ }^{63}$ and acquire citizenship owing to their ascendants. The preferential naturalization does not require the passing of an exam in basic constitutional studies, but it is worth noting that this exam remains to be a criterion for other kinds of naturalisation in Hungary. Compared to the naturalisation of other persons habitually resident in Hungary, the legislator indeed set less stringent requirements for a preferential naturalisation. As a result, the nationality of Hungarians living outside the borders can hardly be considered effective, especially in light of the fact that it is acquired on the basis of the earlier

${ }^{60}$ Act No. CCIII of 2011 on the Election of the Members of Parliament, Art. 12(3).

${ }^{61}$ International Court of Justice, Nottebohm Case (Liechtenstein v. Guatemala), Second Phase, Judgment of 6 April 1955. I.C.J. Reports 1955. 23.

62 Ibid. 22.

63 There is no process for determination of the meaning of providing of proof of knowledge of Hungarian language, thus the request form can be filled out at home and sometimes the proof of knowledge means that the person shall answer in Hungarian some questions regarding his data on the request form. 
nationality of ascendants or the demonstration of the plausibility of Hungarian descent, and a sufficient knowledge of the Hungarian language.

In 2004, in a decision concerning a referendum that, had it been successful, would have offered citizenship to Hungarians living outside the borders upon presenting "a proof of Hungarian nationality", ${ }^{64}$ the Constitutional Court failed to recognise an objection, which sought to draw attention to the lack of real and genuine link. ${ }^{65}$ Judge Kukorelli, however, correctly argued in his dissenting opinion that "a declaration on national status is inadequate to prove the existence the close, real (effective) link between the citizen and the state" ${ }^{66}$ In the present case, the link is closer, but it is hardly genuine.

Bearing all that in mind, the potential consequences of lack of effectiveness on the side of the individual also need to be analysed. First of all, it should be emphasized that the norms of international law concerning nationality do not impose an obligation on states to grant citizenship to persons only in case a genuine link exists. The same applies, of course, to Hungary. Given the difficulties related to the determination of a genuine link, such a norm would allow states to arbitrarily interfere in matters of nationality, which form part of domaine réservé. The intentions of members of the international community do not point toward the framing of such rule.

The academic debate continues on relationship of the principle of effectiveness and the diplomatic protection of individuals possessing one nationality-a topic that was discussed by the International Court of Justice in the Nottebohm Case. In case the principle exists in international law as a customary rule, its content is the following: if diplomatic protection is provided on the basis of an ineffective nationality, the other state has a right not to recognise that nationality. As a consequence of non-recognition, the nationality does not have an effect in the field of international law.

As commonly known, there are two constitutive elements of customary international law: an objective criterion, the general practice of states, and a subjective criterion, the existence of opinio iuris sive necessitatis. ${ }^{67}$ When the above-mentioned judgment was passed, states applied principles in their nationality regulations, which established a genuine link between the individual and the state. ${ }^{68}$ It does not mean, however that their purpose was to create a genuine link in order to bring their regulations in conformity with the principle of effectiveness. ${ }^{69}$ The general practice of states concerning diplomatic protection did not put emphasis on the lack of genuine link either. ${ }^{70}$ In the Nottebohm Case, a reference can be found in the rejoinder submitted by Guatemala for the requirement of an effective

${ }^{64}$ The term "nationality" was used in a historical-biological sense and not as a synonym of "citizenship".

65 Constitutional Court Decision No. 40/2004. paras I, 2, e) and III, 3.

66 Ibid. Dissenting opinion of Judge István Kukorelli, para. 1.

${ }^{67}$ According to Art. 38(1)(b) of the Statute of International Court of Justice, "international custom [is an] evidence of a general practice accepted as law". "Opinio iuris sive necessitatis" means "opinion of law or necessity", a belief of the state that its action is legally obliged.

68 Nottebohm Case (Liechtenstein v. Guatemala), International Court of Justice, Second Phase, Judgment of 6 April 1955. I.C.J. Reports 1955. 22.

69 José Francisco Rezek also mentions that the accordance of domestic regulations is not sufficient to establish the existence of customary international law. Rezek, J. F.: Le droit international de la nationalité. Recueil des Cours, 197 (1986) II, 357.

70 Nottebohm Case (Liechtenstein v. Guatemala), International Court of Justice, Second Phase, Judgment of 6 April 1955. I.C.J. Reports 1955. Dissenting opinion of Judge M. Guggenheim, 55-56. 
link, but it was not supported by the prevailing state practice. ${ }^{71}$ According to the dominant view in contemporary literature, the rule based on the principle of effectiveness could not considered customary international law. ${ }^{72}$ Judges Klaestad, Guggenheim and Read voiced similar considerations in their dissenting opinions. ${ }^{73}$

In sum, the Court accepted the arguments of Guatemala, and its decision was influenced by other principles. ${ }^{74}$ It based its judgment on considerations that were not reflected in the existing sources of international law, thereby taking a "hazardous course" 75 of judicial legislation. Following the publication of the judgment the principle appeared to be noticeable approved, ${ }^{76}$ but later it was increasingly criticized. For instance, it was criticised that the question of effectiveness was determined on the basis of subjective criteria, ${ }^{77}$ the vagueness of which could easily lead to arbitrary implementation. ${ }^{78} \mathrm{~A}$ few years after the judgment in the Nottebohm Case, further objections were raised against the principle of

71 Duplique présentée par le Gouvernement du Guatemala. 2 novembre 1954. Nottebohm Case (Liechtenstein v. Guatemala), International Court of Justice, Second Phase, 511-512. In her countermemorial, Guatemala only referred cases of dual nationality in connection with the principle of effectiveness. See Contre-mémoire présenté par le Gouvernement du Guatemala. 20 avril 1954. Nottebohm Case (Liechtenstein v. Guatemala), International Court of Justice, Second Phase, 195.

72 See Jones, J. M.: The Nottebohm Case. The International and Comparative Law Quarterly, 5 (1956) 2, 243; Parry, C.: Some Considerations upon the Protection of Individuals in International Law. Recueil des Cours, 90 (1956) II, 707; Kunz, J. L.: The Nottebohm Judgment (Second Phase). American Journal of International Law, 54 (1960) 3, 563; Makarov, A. N.: Das Urteil des Internationalen Gerichtshofes im Fall Nottebohm. Zeitschrift für ausländisches öffentliches Recht und Völkerrecht, 16 (1955-1956), 414. See an opposite opinion of Fitzmaurice, G.: The General Principles of International Law Considered from the Standpoint of the Rule of Law. Recueil des Cours, 92 (1957) II, 206-207.

${ }^{73}$ Nottebohm Case (Liechtenstein v. Guatemala), International Court of Justice, Second Phase, Judgment of 6 April 1955. I.C.J. Reports 1955. Dissenting opinion of Judge Klaestad, 31. Dissenting opinion of Judge M. Guggenheim, 56-57, 59. Dissenting opinion of Judge Read, 40.

${ }^{74}$ Such as the prohibition of mala fide or fraudulent naturalisation and the prohibition of abuse of rights. Parry: op. cit. 707; Jones: op. cit. 244.

75 Hersch Lauterpacht did not analyse the Nottebohm Case in his book, but he emphasised that judicial legislation is a hazardous course. Lauterpacht, H.: The Development of International Law by the International Court. London, 1958. 19.

76 de Castro, F.: La nationalité, la double nationalité et la supra-nationalité. Recueil des Cours, 102 (1961) I, 582; Brownlie, I.: The Relations of Nationality in Public International Law. British Year Book of International Law, 39 (1963), 314, 349; Panhuys, H. F. van: The Role of Nationality in International Law. Leiden, 1959. 158; International Resposibility: Sixth Report by F. V. García Amador, Special Rapporteur. Document A/CN.4/134 and Addendum. Yearbook of the International Law Commission, 1961. Vol. II. Documents of the Thirteenth Session Including the Report of the Commission to the General Assembly. United Nations, New York, 1962. 49; Harvard Law School, Convention on the International Responsibility of States for Injuries to Aliens. Draft no. 12 with Explanatory Notes (reporters: Louis B. Sohn-Richard R. Baxter). Cambridge (Mass.), 1961. Art. $23(3)$.

77 Kunz: op. cit. 564; Makarov: op. cit. 418; Parry: op. cit. 711.

78 Perrin, G.: Les conditions de validité de la nationalité en droit international public. In: Recueil d'études de droit international en homage à Paul Guggenheim. Genéve, 1968. 878. Nottebohm Case (Liechtenstein v. Guatemala), International Court of Justice, Second Phase, Judgment of 6 April 1955. I.C.J. Reports 1955. Dissenting opinion of Judge Guggenheim, 55-56. 
effectiveness in the Flegenheimer Case. The Italian-United States Conciliation Commission argued as follows:

"[W]hen a person is vested with only one nationality, which is attributed to him or her either jure sanguinis or jure soli, or by a valid naturalization entailing the positive loss of the former nationality, the theory of effective nationality cannot be applied without the risk of causing confusion. It lacks a sufficiently positive basis to be applied to a nationality which finds support in a state law." 79

In a case analogous to the status of Hungarians living outside the borders, the Conciliation Commission denied that the principle of effectiveness may be applicable to individuals having only one nationality. One of the main arguments of the Commission was that an individual who, in the mobility of modern world, possesses the nationality of a state, but lives in another state, where he is domiciled with his family and where his working place is located, "would be exposed to non-recognition". 80

Nowadays even the binding nature of the principle of effectiveness is in the centre of academic debates. The alteration of the bond of nationality in the modern world obviously rules out the inclusion of the principle in an international treaty as well as its establishment as a rule of customary international law. In 2000, the International Law Commission held a similar view in a report on diplomatic protection:

"The genuine link requirement proposed by Nottebohm seriously undermines the traditional doctrine of diplomatic protection if applied strictly, as it would exclude literally millions of persons from the benefit of diplomatic protection. In today's world of economic globalization and migration, there are millions of persons who have drifted away from their State of nationality and made their lives in States whose nationality they never acquire. Moreover, there are countless others who have acquired nationality by birth, descent or operation of law of States with which they have a most tenuous connection." $" 1$

Following the survey of international treaties, in can be concluded that the principle of effectiveness has not been included in any agreement that could promote its consolidation. The analysis of the alleged customary nature of the principle also reveals that states do not refer to the principle of effectiveness as a basis of non-recognition of nationality. ${ }^{82}$ Hence neither of the elements of customary international law prevails. There is no relevant general

79 Flegenheimer Case, Italian-United States Conciliation Commission, Decision No. 182. 20 September 1958, para. 62. Reports of International Arbitral Awards, Vol. XIV. 377.

80 Ibid.

81 First Report on Diplomatic Protection, by Mr. John R. Dugard, Special Rapporteur. Document A/CN.4/506 and Add.1. Yearbook of the International Law Commission, Vol. II. Part One, Documents of Fifty-Second Session. United Nations, New York-Geneva, 2009. 229. Report refers also Hailbronner, K.: Diplomatischer Schutz bei mehrfacher Staatangehörigkeit. In: Georg, R.-Stein, T. (eds): Der diplomatische Schutz im Völker- und Europarecht: Aktuelle Probleme und Entwicklungstendenzen. Baden-Baden, 1996. 36.

82 First Report on Diplomatic Protection, by Mr. John R. Dugard, Special Rapporteur. Document A/CN.4/506 and Add.1. Yearbook of the International Law Commission, Vol. II. Part One, Documents of Fifty-Second Session. United Nations, New York-Geneva, 2009. 229. 
practice of states nowadays, which is also confirmed by the majority of scholars. ${ }^{83}$ In the lack of general practice, however, the other element of customary international law, the opinio iuris sive necessitatis, cannot even come into existence. For these reasons, the principle of effectiveness may not serve as a basis for other states to declare a nonrecognition of nationality of individuals, who possess only one nationality.

The diplomatic protection of dual nationals vis-à-vis to third states is analogous to the above-mentioned scenario. Similarly to the situation of individuals, who possess only one nationality, the third state may not refer to a lack of effectiveness of nationality of dual nationals in order to substantiate its claim of non-recognition of nationality. Therefore, diplomatic protection can be provided for dual nationals against third states even on the basis of an ineffective nationality. ${ }^{84}$

The lack of effectiveness may give rise to problems in one case though-if diplomatic protection is provided to a dual national by one state of nationality against the other. Suffice it to recall Art. 7 of the Draft Articles on Diplomatic Protection, which is considered by the International Law Commission as a rule of customary nature. ${ }^{85}$ That article reads as follows:

"A State of nationality may not exercise diplomatic protection in respect of a person against a State of which that person is also a national unless the nationality of the former State is predominant [...]." 86

In other words, the claimant state may prove that its nationality is predominant, and as such, it can provide diplomatic protection against the other state of nationality. Interestingly enough, a non-recognition of predominance may even impinge on an effective nationality, because there are exceptional cases, in which both nationalities may be regarded as effective. The lack of predominance does not necessarily follow a lack of effectiveness, but an ineffective nationality is most likely to serve as a basis for the other state of nationality to prove its predominance.

The establishment of this rule may result in exceptional situations, in which another state may exercise diplomatic protection against Hungary in respect of Hungarians living

83 Geck, W. K.: Diplomatic Protection. In: Bernhardt, R. (ed.): Encyclopedia of Public International Law, Vol. 1. Aaland Islands to Dumbarton Oaks Conference (1944). AmsterdamLondon-New York-Tokyo, 1992. 1050; Randelzhofer, A.: Nationality. In: Bernhardt, R. (ed.): Encyclopedia of Public International Law. Vol. 8. Human Rights and the Individual in International Law, International Economic Relations. New York-London, 1982. 421-422; Sloane, R. D.: Breaking the Genuine Link: The Contemporary International Legal Regulation of Nationality. Harvard International Law Journal, 50 (2009) 1, 29-37.

${ }^{84}$ Article 6(1) of the Draft Articles on Diplomatic Protection of International Law Commission also states that "[a]ny State of which a dual or multiple national is a national may exercise diplomatic protection in respect of that national against a State of which that person is not a national." International Law Commission, Draft Articles on Diplomatic Protection, 2006. Art. 6. State practice appears to be uniform regarding this provision, hence the text of Art. 6(1) can be considered as a generally accepted norm.

85 International Law Commission, Draft Articles on Diplomatic Protection with Commentaries, 2006. 46. The first part of the sentence is a generally accepted norm of customary international law, but the exception appears to be a result of progressive development.

${ }^{86}$ International Law Commission, Draft Articles on Diplomatic Protection, 2006. Art. 7. 
outside the borders and possessing the nationality of both states. Simply put, the other state of nationality may provide diplomatic protection against Hungary to a Hungarian national, which is hardly in interest of Hungary.

\section{Obligations Assumed by Bilateral Agreements on Good Neighbourliness and Friendly Co-operation}

Bilateral basic treaties were concluded by Hungary and several neighbouring states, namely Croatia, ${ }^{87}$ Romania, ${ }^{88}$ Slovakia, ${ }^{89}$ Slovenia ${ }^{90}$ and Ukraine, ${ }^{91}$ between 1992 and $1996 .{ }^{92}$ In these treaties states undertook that they develop their relations in the spirit of good neighbourliness, confidence and friendly co-operation, and they establish an appropriate framework for co-operation and maintain a dialogue in all fields of mutual interest. ${ }^{93}$

According to the obligations laid down these basic treaties, Hungary should have initiated negotiations prior to the amendment of the Citizenship Act. Matters of preferential naturalisation of Hungarians living in the neighbouring states and possessing the nationality thereof certainly constitute an area of mutual interest. Slovakia likewise should have negotiated with Hungary before its reaction to the Hungarian legislation with a view to base inter-state relations on good neighbourliness, confidence and friendly co-operation.

In order to ensure and maintain friendly relations, the states concerned should cooperate and consult in every field related to the preferential naturalisation of Hungarians living outside the borders. From the point of view of Hungary, an eventual amendment of the Citizenship Act or an expansion of citizenship rights by means of facilitating their exercise would undoubtedly call for consultations. Neighbouring states, on the other hand, which prohibit dual nationality, should also negotiate with Hungary concerning any future amendments of the legal consequences related to the loss of their nationality.

87 Agreement on Friendly Relations and Co-operation between the Republic of Croatia and the Republic of Hungary. Budapest, 16 December 1992. Entry into force: 21. December 1993.

${ }^{88}$ Treaty between the Republic of Hungary and Romania on Understanding, Co-operation and Good Neighbourhood. Timisoara, 16 September 1996. Entry into force: 27 December 1996.

89 Treaty on Good-Neighbourly Relations and Friendly Co-operation between the Republic of Hungary and the Slovak Republic. Paris, 19 March 1995. Entry into force: 15 May 1996.

90 Treaty on Friendship and Co-operation between the Republic of Hungary and the Republic of Slovenia. Budapest, 1 December 1992. Entry into force: 4 March 1994.

91 Treaty between the Republic of Hungary and Ukraine on the Foundations of Good Neighbourly Relations and Co-operation. Kiev, 6 December 1991. Entry into force: 16 June 1993.

92 In more details see Nagy, K.: Les règles de caractère soft law dans le traités bilatéraux de la Hongrie conclus sur la protection des minorités. In: Kovács, P. (ed.): Le droit international au tournant de millénaire-l'approche Hongroise. International Law at the Turn of the Millennium-the Hungarian Approach. Budapest, 2000. 18-24.

93 Agreement on Friendly Relations and Co-operation between the Republic of Croatia and the Republic of Hungary, Arts 1, 8; Treaty between the Republic of Hungary and Romania on Understanding, Co-operation and Good Neighbourhood, Arts 1, 5; Treaty on Good-Neighbourly Relations and Friendly Co-operation between the Republic of Hungary and the Slovak Republic, Arts 1, 5; Treaty on Friendship and Co-operation between the Republic of Hungary and the Republic of Slovenia, Arts 1, 7; Treaty between the Republic of Hungary and Ukraine on the Foundations of Good Neighbourly Relations and Co-operation, Arts 1, 5. 


\section{Summary}

Matters on nationality fall within the domestic jurisdiction of states, and form part of domaine réservé, in which states enjoy absolute discretion. Given that the discretion of states encompasses the undertaking of international obligations concerning such matters, the international legal framework needs to be analysed, as well.

Human rights obligations of states limit the domestic regulation of acquisition and loss of nationality in certain cases, particularly in view of the fact that the development of international law has led to the removal of human rights issues from the domaine réservé of states. Since the purpose of the right to a nationality was undoubtedly to eliminate statelessness, the phrase "[e]veryone has a right to a nationality" includes both the right to acquisition and retention of nationality. However, it can be construed neither as a human right of dual nationality nor as a prohibition of dual nationality. The prohibition of arbitrary deprivation of nationality does not cover dual or multiple nationals, who still possess at least one nationality after the losing of a nationality by way of deprivation. Consequently, the regulation of certain states, according to which persons lose their nationality in the wake of the acquisition of another nationality, is in conformity with international law. In the neighbouring states, a possible violation of the prohibition of discrimination may occur in Slovakia only. Discrimination between cases on facts may occur as a result of marriage, when the Slovak nationality can be retained even if the individual acquires another nationality at his or her request.

The purpose of the Hungarian amendment was primarily to provide a symbolic Hungarian nationality for ethnic Hungarians living outside the borders. Even so the lack of effectiveness may give rise to problems. It is unquestionable that non-resident Hungarians acquire an ineffective nationality, and Hungary is not obliged by international law to grant an effective nationality. Since the principle of effectiveness does not have customary nature in international law, Hungary may exercise diplomatic protection in respect of individuals possessing either one or dual nationality, but in the latter case she may do so against third states only. Problems may arise in a case of diplomatic protection of dual nationals between the respective states of nationality. A possible consequence of the lack of effectiveness of nationality of Hungarians living outside the borders may be that Hungary cannot exercise diplomatic protection in respect of them. The other state of nationality, however, can exercise diplomatic protection in respect of Hungarian nationals against Hungary. The nationality of an individual needs to be further analysed if he or she becomes an effective national owing to a permanent residency or a working place in Hungary, which ends his or her de facto stateless status.

The initiation of meaningful negotiations and the promotion of a constructive cooperation, as envisaged by the bilateral basic treaties, would be essential for the development of inter-state relations and for the protection of individuals, who have or will become Hungarian nationals. Without dialogue and conciliation in this field, only the emergence of further problems appears certain. 